\title{
Pengaruh Desentralisasi Fiskal Terhadap Pertumbuhan Ekonomi Kabupaten/Kota Di Provinsi Sumatera Utara Tahun 2011-2019
}

\author{
Province in 2011-2019) \\ Alwi Adha Pohan ${ }^{1 *}$, Lia Yuliana ${ }^{2}$ \\ ${ }^{1,2}$ Politeknik Statistika STIS \\ Jalan Otto Iskandardinata No. 64C Jakarta Timur \\ E-mail: 211709535@stis.ac.id
}

(The Effect of Fiscal Decentralization on Economic Growth of Districts/Cities in North Sumatera

\begin{abstract}
ABSTRAK
Keberhasilan pelaksanaan desentralisasi fiskal akan menunjukkan tercapainya kesejahteraan masyarakat dengan peningkatan pertumbuhan ekonomi. Akan tetapi yang terjadi pada Provinsi Sumatera Utara, terdapat indikasi bahwa kesejahteraan masyarakat belum tercapai. Hal ini terlihat dari pertumbuhan ekonomi kabupaten/kota selama periode 2011-2019 menunjukkan peningkatan yang melambat dan tidak merata. Sehingga tujuan dalam penelitian ini adalah menggambarkan secara umum nilai PDRB, rasio PAD, rasio DBH, rasio DAU, dan rasio DAK serta mengetahui pengaruh desentralisasi fiskal terhadap pertumbuhan ekonomi kabupaten/kota di Provinsi Sumatera Utara. Analisis regresi data panel terbaik menggunakan fixed effects. Hasil penelitian diperoleh bahwa secara parsial rasio PAD dan rasio DAK berpengaruh positif signifikan terhadap pertumbuhan ekonomi sedangkan rasio DBH dan rasio DAU berpengaruh negatif dan tidak signifikan terhadap pertumbuhan ekonomi. Dengan demikian pemerintah Kabupaten/Kota dapat meningkatkan nilai rasio PAD dan rasio DAK agar terjadi peningkatan pertumbuhan ekonomi.
\end{abstract}

Kata kunci: pertumbuhan ekonomi, desentralisasi fiskal, regresi data panel

\section{ABSTRACT}

The successful implementation of fiscal decentralization will show the achievement of public welfare by increasing economic growth. However, what happened in North Sumatra, there are indications that public welfare has not been achieved. This can be seen from the economic growth of districts/cities during 2011-2019 period which shows a slow and uneven increase. So the purpose of this study is to describe in general the value of PDRB, the PAD ratio, the DBH ratio, the DAU ratio, and the DAK ratio and to know the effect of fiscal decentralization on the economic growth of districts/cities in North Sumatra. The best panel data regression analysis uses fixed effects. The results showed that partially the PAD ratio and the DAK ratio had a positive and significant effect on economic growth, while the DBH ratio and DAU ratio had a negative and insignificant effect on economic growth. Thus the district/cities government can increase the value of PAD ratio and the DAK ratio in order to increase the economic growth.

Keywords: economic growth, fiscal decentralization, panel data regression

\section{PENDAHULUAN}

Kesejahteraan masyarakat merupakan tanggung jawab dari negara. Sebagaimana tercantumkan pada citacita bangsa Indonesia yaitu memajukan kesejahteraan umum. Kesejahteraan dapat diukur menggunakan indikator pertumbuhan ekonomi. Pertumbuhan ekonomi dapat memperlihatkan bagaimana kinerja pemerintah pusat maupun pemerintah daerah dalam rangka mengelola pemerintahan. Pengelolaan pemerintahan yang baik akan membawa pertumbuhan ekonomi menjadi lebih baik dengan tercapainya kesejahteraan masyarakat.

Harapan pemerintah untuk mendapatkan pertumbuhan ekonomi yang stabil dan merata telah terwujud sejak Januari 2001 dengan terlaksananya otonomi daerah serta desentralisasi fiskal. Gagasan otonomi daerah ini menjadikan Indonesia menganut sistem desentralisasi. Dalam pelaksanaannya, pengambilan kebijakan yang selama ini terpusat diserahkan ke daerah sebagai perwujudan pemerintah pusat. Mengutip pendapat Oates (1999) bahwa pemerintah pusat lebih baik mendelegasikan tugas dan wewenang kepada pemerintah daerah agar kebijakan yang dihasilkan lebih sesuai dengan kebutuhan masyarakat.

Menurut Sidik dalam (Rahman, 2012) bahwa tujuan dari kebijakan desentralisasi fiskal adalah dapat menjamin: "(1) kesinambungan kebijakan fiskal dalam struktur ekonomi makro; (2) peningkatan efisiensi alokasi sumber daya nasional dengan mengadakan koreksi atas ketimpangan antar daerah maupun pusat; (3) pemenuhan perbaikan struktur fiskal serta penyaluran pendapatan baik secara menyeluruh; (4) peningkatan akuntabilitas, transparansi, dan partisipasi masyarakat pada tingkat daerah dalam pengambilan keputusan; (5) 
perbaikan pemerataan fiskal antar daerah dengan diikuti kualitas pelayanan yang baik di setiap daerah; dan (6) terciptanya kesejahteraan masyarakat secara sosial".

Qomariyahti dan Hermanto (2017) menyatakan bahwa meningkatnya rasio PAD, rasio DAU, dan rasio DAK sebagai bagian dari desentralisasi fiskal akan menyebabkan pertumbuhan ekonomi tumbuh secara positif. Begitu juga Eliza, Muhammad, dan Nasir (2014) bahwa peningkatan PDRB di Provinsi Aceh dipengaruhi oleh peningkatan DAU dan DBH. Kusumawati dan Wiksuana (2018) menemukan bahwa rasio PAD dan rasio DAK memiliki pengaruh positif terhadap pertumbuhan ekonomi di Provinsi Bali.

Implementasi desentralisasi fiskal dan otonomi daerah pada Provinsi Sumatera Utara ternyata tidak serta merta membawa peningkatan kesejahteraan masyarakat. Padahal terjadi peningkatan jumlah dana yang ditransfer ke daerah setiap tahunnya. Jika dilihat pertumbuhan ekonomi pada tahun 2011, Provinsi Sumatera Utara memperoleh sebesar 6,66 persen. Lalu mengalami penurunan yang cukup signifikan sebesar 1,56 persen, sehingga pada tahun 2015 hanya mencapai 5,1 persen. Penurunan tersebut sangat tinggi dibandingkan dengan penurunan pada provinsi lainnya.

Berdasarkan uraian diatas dengan melihat bahwa keadaan perekonomian Provinsi Sumatera Utara yang cenderung menurun mengharuskan perlu dilakukan penelitian agar mengetahui pengaruh desentralisasi fiskal terhadap pertumbuhan ekonomi kabupaten/kota di Provinsi Sumatera Utara. Dalam hal ini pertumbuhan ekonomi diproksikan melalui PDRB serta desentralisasi fiskal dicerminkan melalui rasio keuangan yaitu rasio PAD, rasio DBH, rasio DAU, dan rasio DAK. Penelitian ini bertujuan untuk mengetahui gambaran umum nilai PDRB, rasio PAD, rasio DBH, rasio DAU, dan rasio DAK serta mengetahui pengaruh desentralisasi fiskal terhadap pertumbuhan ekonomi kabupaten/kota di Provinsi Sumatera Utara tahun 2011-2019.

\section{METODE}

\section{Pertumbuhan Ekonomi}

Todaro (2006) menyatakan bahwa pertumbuhan ekonomi merupakan sebuah proses secara terus menerus dengan peningkatan kapasitas produktif yang berkesinambungan dalam periode yang panjang dan akan menghasilkan output yang besar bagi perekonomian dan pendapatan. Dengan kata lain, pertumbuhan ekonomi dapat terjadi apabila pendapatan masyarakat bertambah sesuai dengan aktivitas perekonomian dalam satu periode tertentu. Jika dalam perspektif ekonomi makro, pertumbuhan ekonomi adalah penambahan Produk Domestik Bruto (PDB) untuk nasional dan penambahan Produk Domestik Regional Bruto (PDRB) untuk daerah.

PDRB menurut BPS merupakan penjumlahan nilai tambah yang diperoleh dari seluruh unit usaha dalam suatu daerah tertentu atau merupakan jumlah nilai barang dan jasa akhir yang dihasilkan dari seluruh unit ekonomi dalam daerah tertentu. PDRB ADHB merupakan perhitungan nilai tambah barang dan jasa menggunakan harga pada tahun berjalan. PDRB ADHB digunakan untuk menggambarkan pergeseran struktur ekonomi dan kemampuan ekonomi suatu daerah. Sementara itu, PDRB ADHK menunjukkan perhitungan nilai tambah barang dan jasa menggunakan tahun dasar dengan harga pada satu tahun tertentu. PDRB ADHK digunakan untuk mengetahui perbandingan pertumbuhan ekonomi dari tahun ke tahun. Olehkarena itu, indikator PDRB menjadi tolak ukur keberhasilan pemerintah daerah dalam mengelola sumber daya daerah untuk kepentingan masyarakat.

\section{Desentralisasi Fiskal}

Desentralisasi fiskal merupakan sebuah wewenang yang diberikan kepada daerah untuk dapat mengelola sumber-sumber pendapatan, penerimaan transfer dari pemerintah pusat yang lebih tinggi, dan penentuan belanja rutin dan investasi (Litvack, 1998). Kebijakan diatas tertuang dalam undang-undang yang mengatur tentang keuangan antara Pemerintah Pusat dengan daerah. Pengelolaan desentralisasi fiskal dapat diuraikan menjadi Pendapatan Asli Daerah (PAD), Dana Perimbangan (Dana Bagi Hasil, Dana Alokasi Umum, dan Dana Alokasi Khusus), dan lain-lain pendapatan daerah yang sah.

\section{Hubungan Desentralisasi Fiskal dengan Pertumbuhan Ekonomi}

Menurut Martinez dan Mcnab (2003) bahwa ada keterikatan desentralisasi fiskal dan pertumbuhan ekonomi yang bersifat multidimensional baik berupa direct maupun indirect sehingga sulit untuk menentukan hubungan yang optimal. Lebih lanjut lagi World Bank (1997) ada tiga kemungkinan kondisi yang terjadi akibat keterikatan desentralisasi fiskal dan pertumbuhan ekonomi yakni: pertama, desentralisasi fiskal berdampak positif terhadap pertumbuhan ekonomi akibat pengeluaran pemerintah lebih efisien; kedua, desentralisasi 
fiskal berdampak negatif terhadap pertumbuhan ekonomi akibat peningkatan instabilitas makro ekonomi; ketiga, desentralisasi fiskal dapat berdampak positif maupun negatif terhadap pertumbuhan ekonomi, dengan memperhatikan kemampuan daerah untuk melaksanakan desentralisasi fiskal.

\section{Model Analisis}

Penelitian ini menggunakan analisis deskriptif dan analisis inferensia. Secara deskriptif ditujukan dalam menggambarkan variabel bebas dan variabel tak bebas secara umum. Secara inferensia menggunakan analisis regresi data panel yang bertujuan untuk melihat bagaimana pengaruh rasio PAD, rasio DBH, rasio DAU, dan rasio DAK terhadap pertumbuhan ekonomi di Provinsi Sumatera Utara tahun 2011-2019.

Terdapat tiga spesifikasi model dalam regresi data panel yang dapat terbentuk berdasarkan tiga pengujian melalui uji Chow, uji Hausman, dan uji Breuch-Pagan Lagrange Multiplier, adalah sebagai berikut (Greene, 2003):

1. Common Effects Model

$$
\ln P D R B_{i t}=\alpha+\beta_{1} r P A D_{i t}+\beta_{2} r D B H_{i t}+\beta_{3} r D A U_{i t}+\beta_{4} r D A K_{i t}+\varepsilon_{i t}
$$

2. Fixed Effects Model

$$
\ln P D R B_{i t}=\left(\alpha+u_{i}\right)+\beta_{1} r P A D_{i t}+\beta_{2} r D B H_{i t}+\beta_{3} r D A U_{i t}+\beta_{4} r D A K_{i t}+v_{i t}
$$

3. Random Effects Model

$$
\ln P D R B_{i t}=\alpha+\beta_{1} r P A D_{i t}+\beta_{2} r D B H_{i t}+\beta_{3} r D A U_{i t}+\beta_{4} r D A K_{i t}+\left(u_{i}+v_{i t}\right)
$$

\section{Keterangan:}

$\ln P D R B_{i t} \quad=$ logaritma natural PDRB ADHK kabupaten/kota ke $-\mathrm{i}$ tahun $\mathrm{ke}-\mathrm{t}$

$\alpha \quad=$ intersep

$\beta_{1}, \ldots, \beta_{4} \quad=$ nilai koefisien regresi masing-masing variabel

$r P A D_{i t} \quad=$ rasio PAD kabupaten atau kota ke-i tahun ke-t

$r D B H_{i t} \quad=$ rasio DBH kabupaten atau kota ke-i tahun ke-t

$r D A U_{i t} \quad=$ rasio DAU kabupaten atau kota ke-i tahun ke-t

$r D A K_{i t} \quad=$ rasio DAK kabupaten atau kota ke-i tahun ke-t

$u_{i} \quad=$ efek individu

$\varepsilon_{i t} \quad=$ error term gabungan dari individu ke-i tahun ke-t

$v_{i t} \quad=$ error term dari individu ke-i tahun ke-t

$i \quad=1,2, \ldots, 33$ (33 kabupaten atau kota)

$t \quad=1,2, \ldots, 9(2011-2019)$

Adapun beberapa tahapan yang dilakukan dalam penelitian ini untuk mendapatkan hasil terbaik adalah sebagai berikut:

1. Penggunaan uji Chow, uji Hausman, dan uji Breuch-Pagan Lagrange Multiplier untuk mendapatkan model paling baik;

2. Jika model CEM atau FEM terpilih maka dilakukan pengujian struktur matriks varians-kovarians residual dengan uji LM dan uji $\lambda_{L M}$;

3. Melakukan pengujian asumsi klasik. Jika menggunakan metode OLS beberapa asumsi seperti normalitas, homoskedastis, nonautokorelasi, dan nonmultikolinieritas harus terpenuhi. Apabila menggunakan metode GLS atau FGLS maka hanya asumsi normalitas dan nonmultikolinieritas yang harus terpenuhi;

4. Melakukan uji simultan (uji-F), dan uji parsial (uji-t) serta melihat keberartian model dengan menggunakan koefisien determinasi $\left(R^{2}\right)$;

5. Menginterpretasi hasil estimasi model yang terbentuk.

\section{Data dan Sumber Data}

Dalam penelitian ini menggunakan data sekunder dalam bentuk data panel dari 33 kabupaten/kota di Provinsi Sumatera Utara dengan periode waktu dari tahun 2011-2019. Adapun rinciannya adalah data PDRB ADHK bersumber dari hasil publikasi BPS, sementara data total pendapatan daerah, Pendapatan Asli Daerah, Dana Bagi Hasil, Dana Alokasi Umum, dan Dana Alokasi Khusus bersumber dari hasil visualisasi data APBD oleh DJPK Kemenkeu. 


\section{HASIL DAN PEMBAHASAN}

\section{Gambaran PDRB kabupaten/kota di Provinsi Sumatera Utara}

Secara umum terjadi peningkatan PDRB ADHK tiap kabupaten/kota di Provinsi Sumatera Utara. Gambar 1 menunjukkan nilai PDRB ADHK mengalami peningkatan yang sampai tahun 2019. Rata - rata PDRB ADHK kabupaten/kota pada tahun 2011 adalah sebesar Rp 10,66 triliun dengan nilai tertinggi sebesar Rp 97,67 triliun oleh Kota Medan dan terendah oleh Kabupaten Pakpak Bharat hanya sebesar Rp 538 miliar. Selanjutnya pada tahun 2019, rata - rata PDRB ADHK kabupaten/kota berkisar sebesar Rp 16,55 triliun. Kota medan juga menjadi daerah dengan nilai tertinggi yakni sebesar Rp 156,78 triliun dan Kabupaten Pakpak Bharat tetap menjadi yang terendah yakni hanya sebesar Rp 852 miliar.

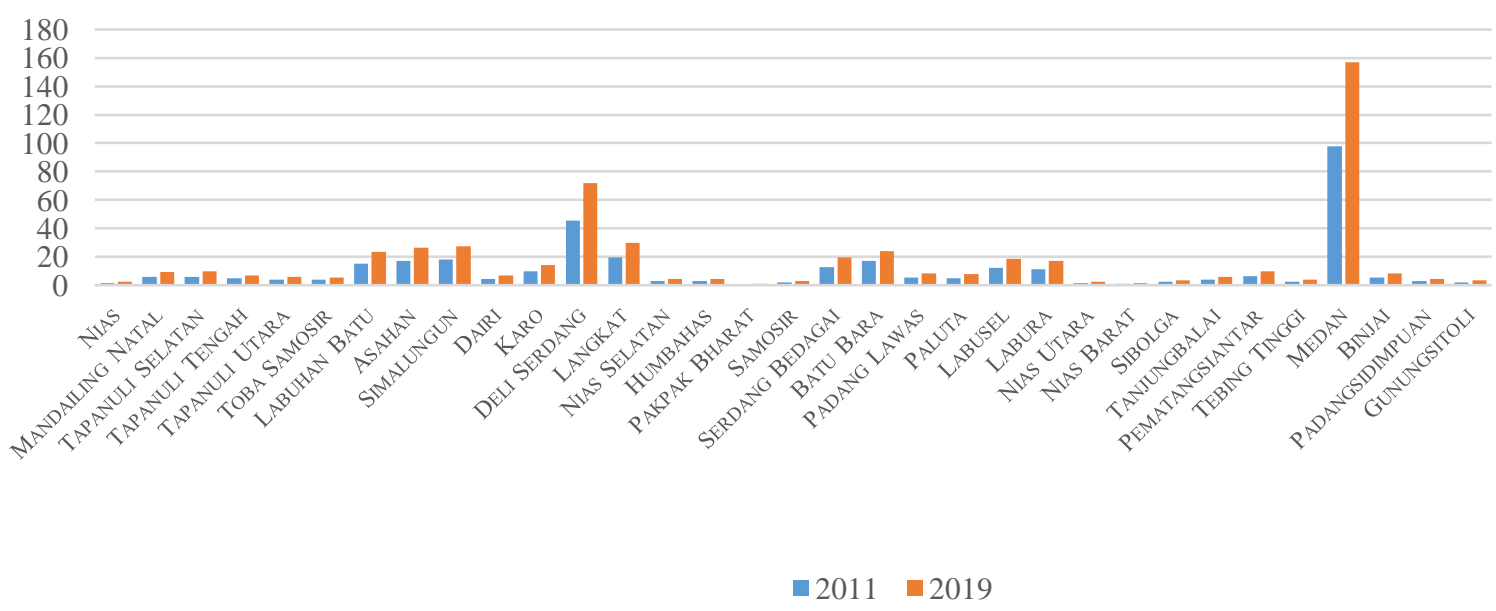

Sumber: Badan Pusat Statistik (diolah)

Gambar 1. Nilai PDRB ADHK kabupaten/kota di Provinsi Sumatera Utara tahun 2010 dan tahun 2019 (dalam triliun rupiah).

\section{Gambaran rasio PAD kabupaten/kota di Provinsi Sumatera Utara}

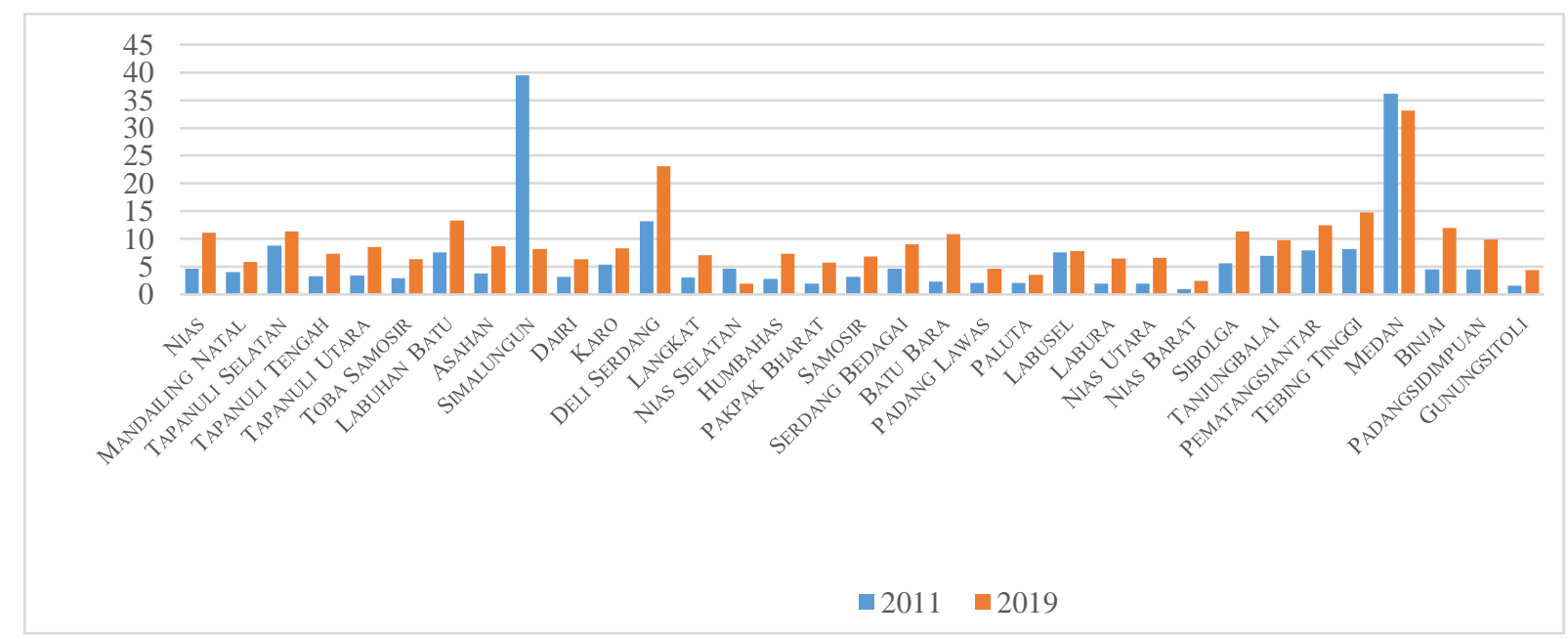

Sumber: DJPK (diolah)

Gambar 2. Rasio PAD kabupaten/kota terhadap total pendapatan daerah di Provinsi Sumatera Utara antara tahun 2011 dan tahun 2019 (dalam persen).

Peningkatan nilai PAD tahun 2011 sampai tahun 2019 diikuti oleh semakin besarnya kontribusi PAD terhadap seluruh pendapatan daerah masing-masing kabupaten/kota. Hanya beberapa daerah yang mengalami penurunan yakni Kabupaten Simalungun, Kabupaten Nias Selatan dan Kota Medan (Gambar 2). Pada tahun 2011 Kabupaten Simalungun memiliki kontribusi PAD tertinggi mencapai 39,44 persen, lalu Kabupaten Nias Barat memiliki kontribusi PAD terkecil hanya 0,97 persen. Sementara pada tahun 2019 kontribusi PAD tertinggi didapatkan oleh Kota Medan sebesar 33,15 persen dan kontribusi PAD terkecil didapatkan oleh Kabupaten Nias Selatan yaitu hanya 1,95 persen. Disamping itu secara rata - rata kontribusi PAD hanya 
berkisar 9,29 persen pada tahun 2019 yang artinya kabupaten/kota di Provinsi Sumatera Utara memiliki tingkat kemandirian yang rendah.

\section{Gambaran rasio DBH kabupaten/kota di Provinsi Sumatera Utara}

Penurunan nilai DBH juga diikuti oleh semakin kecilnya kontribusi DBH terhadap seluruh pendapatan daerah masing-masing kabupaten/kota. Peningkatan hanya terjadi pada Kabupaten Tapanuli Selatan dan penurunan paling signifikan terjadi pada Kota Medan. Pada tahun 2011, Kabupaten Langkat memiliki kontribusi DBH tertinggi mencapai 12,43 persen, lalu Kabupaten Nias memiliki kontribusi DBH terkecil hanya 2,85 persen (Gambar 3). Sementara pada tahun 2019 kontribusi DBH tertinggi didapatkan Kabupaten Tapanuli Selatan sebesar 8,97 persen dan kontribusi DBH terkecil didapatkan Kabupaten Nias Selatan yaitu hanya 0,90 persen. Disamping itu secara rata - rata kontribusi PAD hanya berkisar 2,29 persen pada tahun 2019.

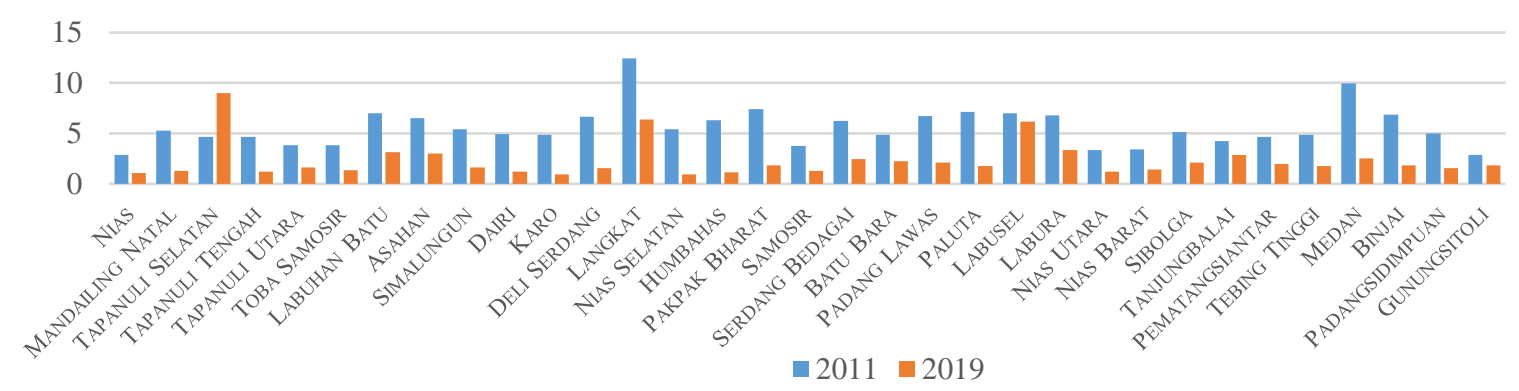

Sumber: DJPK (diolah)

Gambar 3. Rasio DBH kabupaten/kota terhadap total pendapatan daerah di Provinsi Sumatera Utara antara tahun 2011 dan tahun 2019 (dalam persen).

\section{Gambaran rasio DAU kabupaten/kota di Provinsi Sumatera Utara}

Peningkatan nilai DAU berbanding terbalik dengan semakin kecilnya kontribusi DAU terhadap seluruh pendapatan daerah masing-masing kabupaten/kota. Peningkatan tertinggi didapatkan oleh Kota Binjai dan penurunan tertinggi terjadi pada Kabupaten Nias Utara (Gambar 4). Pada tahun 2011 Kota Tanjung Balai memiliki kontribusi DAU tertinggi mencapai 70,60 persen, lalu Kota Medan memiliki kontribusi DAU terkecil hanya 38,81 persen. Sementara pada tahun 2019 kontribusi DAU tertinggi didapatkan oleh Kota Sibolga sebesar 69,13 persen dan kontribusi DAU terkecil didapatkan oleh Kota Medan yaitu hanya 30,08 persen. Disamping itu secara rata - rata kontribusi DAU hanya berkisar 52,90 persen pada tahun 2019.

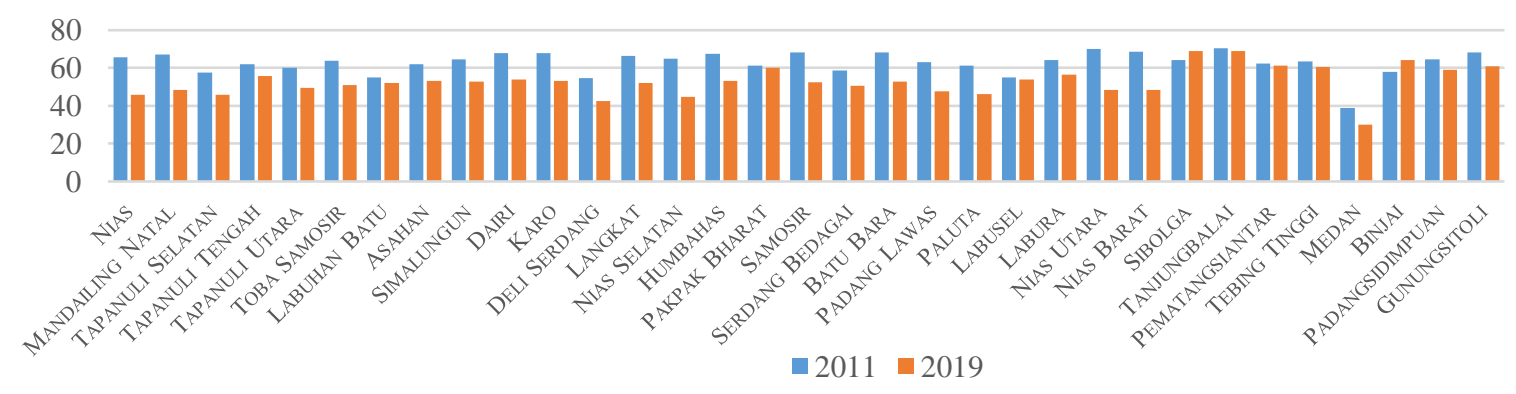

Sumber: DJPK (diolah)

Gambar 4. Rasio DAU kabupaten/kota terhadap total pendapatan daerah di Provinsi Sumatera Utara antara tahun 2011 dan tahun 2019 (dalam persen).

\section{Gambaran rasio DAK kabupaten/kota di Provinsi Sumatera Utara}

Peningkatan nilai DAK tahun 2011 sampai tahun 2019 juga diikuti oleh semakin besarnya kontribusi DAK terhadap seluruh pendapatan daerah masing-masing kabupaten/kota. Hanya Kota Gunung Sitoli yang mengalami penurunan (Gambar 13). Peningkatan tertinggi didapatkan oleh Kabupaten Nias Utara dan penurunan tertinggi terjadi pada Kota Gunung Sitoli. Pada tahun 2011 Kabupaten Nias Barat memiliki kontribusi DAK tertinggi mencapai 16,93 persen, lalu Kota Medan memiliki kontribusi DAK terkecil hanya 2,96 persen. Sementara pada tahun 2019 kontribusi DAK tertinggi didapatkan oleh Kabupaten Nias Barat 
sebesar 26,05 persen dan kontribusi DAK terkecil didapatkan oleh Kota Medan yaitu hanya 6,47 persen. Disamping itu secara rata - rata kontribusi DAK hanya berkisar 15,41 persen pada tahun 2019.

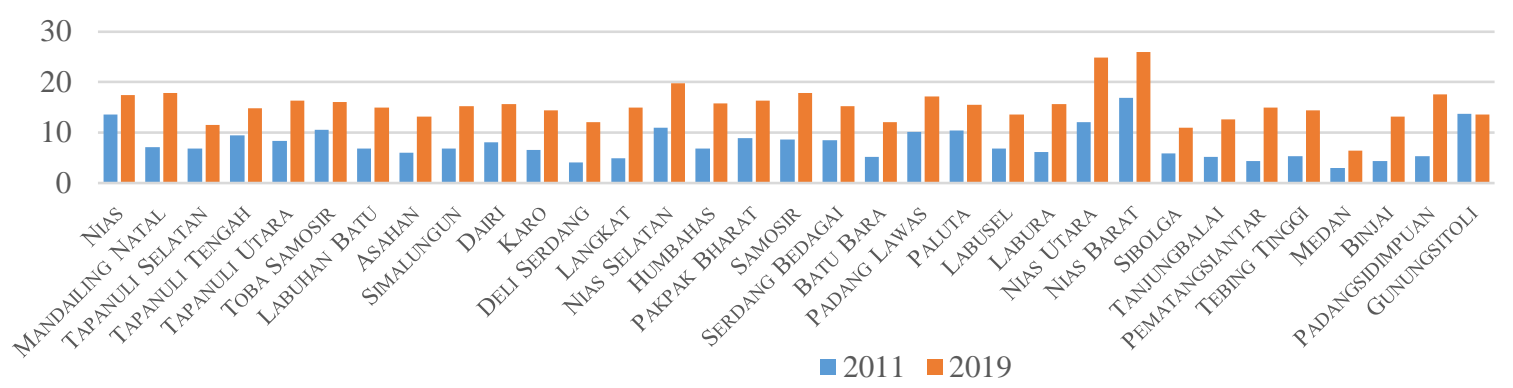

Sumber: DJPK (diolah)

Gambar 5. Rasio DAK kabupaten/kota terhadap total pendapatan daerah di Provinsi Sumatera Utara antara tahun 2011 dan tahun 2019 (dalam persen).

\section{Pengaruh Desentralisasi Fiskal Terhadap Pertumbuhan Ekonomi di Provinsi Sumatera Utara Tahun 2011-2019}

\section{Pemilihan Model Regresi Terbaik}

Uji Chow dilakukan untuk mendapatkan model terbaik diantara Common Effects dan Fixed Effects. Uji Hausman dilakukan untuk mendapatkan model terbaik antara Fixed Effects dan Random Effects. Dengan demikian, berdasarkan Tabel 1. menghasilkan kesimpulan bahwa model terbaik yang akan digunakan adalah FEM. Kemudian dilanjutkan dengan pengujian struktur varians-kovarians residual.

Tabel 1. Ringkasan pengujian.

\begin{tabular}{ccccc}
\hline Jenis Uji & Statistik Uji & $p$-value & Keputusan & Kesimpulan \\
\hline Uji Chow & 207,183841 & 0,0000 & Tolak $H_{0}$ & FEM terbaik \\
Uji Hausman & 76,855422 & 0,0000 & Tolak $H_{0}$ & FEM terbaik \\
\hline
\end{tabular}

\section{Pengujian Struktur Matriks Varians-Kovarians Residual}

Berdasarkan Tabel 2. uji LM dilakukan dalam memeriksa apakah struktur matriks varians-kovarians dari residual model terpilih memiliki sifat homoskedastis atau heteroskedastis. Berdasarkan hasil pengujian, diperoleh nilai LM sebesar 147.533762 dan nilai $\chi^{2}$ tabel (32) sebesar 46,19. Sehingga demikian menghasilkan keputusan tolak $H_{0}$, yaitu dengan tingkat signifikansi $5 \%$ kesimpulan yang diperoleh bahwa varians-kovarians residual bersifat heteroskedastis. Selanjutnya, dilakukan uji $\lambda_{L M}$ untuk mengetahui ada tidaknya cross sectional correlation. Berdasarkan hasil pengujian, diperoleh nilai $\lambda_{L M}$ sebesar 1183.41752 dan nilai $\chi^{2}$ tabel (528) sebesar 582,56. Sehingga demikian menghasilkan keputusan tolak $H_{0}$, yaitu dengan tingkat signifikansi $5 \%$ kesimpulan yang diperoleh bahwa varians-kovarians residual terdapat cross sectional correlation.

Tabel 2. Ringkasan pengujian.

\begin{tabular}{ccccc}
\hline Jenis Uji & Statistik Uji & $\chi^{2}$ tabel & Keputusan & Kesimpulan \\
\hline Uji LM & 147,533762 & 46,19 & Tolak $H_{0}$ & Heteroskedastis \\
Uji $\lambda_{L M}$ & 1183,41752 & 582,56 & Tolak $H_{0}$ & Terdapat cross sectional \\
& & & & correlation \\
\hline
\end{tabular}

Kesimpulan yang diperoleh dari pengujian diatas adalah model estimasi paling baik untuk dipergunakan dalam penelitian kali ini adalah Fixed Effects Model dengan struktur varians-kovarians residual bersifat heteroskedastis dan terdapat cross sectional correlation, dan metode estimasi yang digunakan adalah Seemingly Unrelated Regressions (SUR). Dikarenakan keterbatasan metode SUR yang hanya bisa digunakan jika jumlah unit waktu melebihi dari unit individu, sehingga digunakan metode SUR (PCSE) untuk mengatasinya.

\section{Pengujian Asumsi Klasik}

Pengujian asumsi normalitas dilakukan untuk memperoleh informasi apakah error term berdistribusi secara normal atau tidak. Pengujian dilakukan dengan uji Jarque-Bera. Berdasarkan hasil pengujian pada Tabel 3. diperoleh nilai $p$-value sebesar 0,60 bernilai lebih besar dari $\alpha$ sebesar 0,05 . Sehingga demikian menghasilkan keputusan gagal tolak $H_{0}$, yaitu dengan tingkat signifikansi 5\% diperoleh kesimpulan bahwa residual berditribusi normal. 
Tabel 3. Ringkasan pengujian

\begin{tabular}{ccccc}
\hline Jenis Uji & Statistik Uji & $p$-value & Keputusan & Kesimpulan \\
\hline Jarque-Bera & 0,995692 & 0,60 & Gagal tolak $H_{0}$ & Residual berdistribusi normal \\
\hline
\end{tabular}

Pengujian asumsi nonmultikolinieritas digunakan untuk menghindari adanya hubungan linear antarvariabel bebas pada model. Dari Tabel 4. diperoleh nilai dari seluruh variabel bebas kurang dari sepuluh. Sehingga demikian bahwa asumsi nonmultikolinieritas terpenuhi.

Tabel 4. Ringkasan nilai VIF

\begin{tabular}{cc}
\hline Variabel bebas & VIF \\
\hline Rasio PAD & 1,143309 \\
Rasio DBH & 1,416307 \\
Rasio DAU & 1,234573 \\
Rasio DAK & 1,304888 \\
\hline
\end{tabular}

\section{Estimasi Model}

Berdasarkan Tabel 5. diperoleh nilai $R^{2}$ adjusted sebesar 0,9971. Dengan demikian menghasilkan makna bahwa variabel bebas yang termasuk dalam model secara keseluruhan yaitu rasio PAD, rasio DBH, rasio DAU, dan rasio DAK dapat menjelaskan variabel tak bebas yaitu pertumbuhan ekonomi sebesar 99,71 persen. Sementara sisanya sebesar 0,29 persen dijelaskan oleh variabel lain di luar model yang diteliti.

Tabel 5. Ringkasan hasil analisis model regresi.

\begin{tabular}{ccccc}
\hline Variabel Bebas & Koefisien & $t$-Statistic & $t$-Tabel & Keputusan \\
\hline C & 8.969366 & 139.3952 & \\
rPAD & 0.009787 & 4.106365 & 1.96913 & Signifikan \\
rDBH & -0.044689 & -7.418038 & 1.96913 & Tidak Signifikan \\
rDAU & -0.002602 & -2.421653 & 1.96913 & Tidak Signifikan \\
rDAK & 0.008467 & 4.040066 & 1.96913 & Signifikan \\
\hline \multicolumn{5}{c}{ Ringkasan Statistik } \\
\hline F-statistic & 2921.617 & Prob (F-statistic) & 0.000000 & \\
R -squared & 0.997534 & & & \\
Adjusted R -squared & 0.997193 &
\end{tabular}

Berdasarkan Tabel 5. penulisan model estimasi adalah sebagai berikut:

$\ln \widehat{P D R} B_{i t}=\left(8,969366+u_{i}\right)+0,009787 r P A D_{i t}{ }^{*}-0,044689 r D B H_{i t}-0,002602 r D A U_{i t}+$ $0,008467 r D A K_{i t}{ }^{*}$

Keterangan:

$\operatorname{lnPDRB_{it}} \quad=$ logaritma natural PDRB ADHK kabupaten atau kota ke-i tahun ke-t

$r P A D_{i t} \quad=$ rasio PAD kabupaten atau kota ke-i tahun ke-t

$r D B H_{i t} \quad=$ rasio DBH kabupaten atau kota ke-i tahun ke-t

$r D A U_{i t} \quad=$ rasio DAU kabupaten atau kota ke-i tahun ke-t

$r D A K_{i t} \quad=$ rasio DAK kabupaten atau kota ke-i tahun ke-t

$u_{i} \quad=$ efek individu

$\varepsilon_{i t} \quad=$ error term gabungan dari individu ke-i tahun ke-t

$v_{i t} \quad=$ error term dari individu ke-i tahun ke-t

$i \quad=1,2, \ldots, 33$ (33 kabupaten atau kota)

$t \quad=1,2, \ldots, 9(2011-2019)$

Dari hasil pengujian pada Tabel 5. dihasilkan F statistik yaitu 2921,617 dan F tabel (36,260) yaitu 1,46. Dengan hasil tersebut nilai $\mathrm{F}$ statistik bernilai lebih besar dari nilai $\mathrm{F}$ tabel dan diikuti dengan nilai probability $(F$-statistic) sebesar 0,00 bernilai lebih kecil dari $\alpha$ sebesar 0,05 . Sehingga demikian menghasilkan keputusan tolak $H_{0}$, yaitu dengan tingkat signifikansi $5 \%$ diperoleh kesimpulan bahwa terdapat minimal satu variabel bebas yang berpengaruh signifikan terhadap pertumbuhan ekonomi.

Dari hasil pengujian pada Tabel 5. dihasilkan nilai (t-statistic) variabel rasio PAD dan rasio DAK lebih besar daripada nilai t tabel (260) sebesar 1,96913. Dengan hasil tersebut menghasilkan keputusan tolak $H_{0}$, yaitu dengan tingkat signifikansi 5\% diperoleh kesimpulan bahwa variabel rasio PAD dan rasio DAK berpengaruh secara positif signifikan terhadap pertumbuhan ekonomi. 


\section{Interpretasi Model}

Berdasarkan hasil yang diperoleh dari analisis yang dilakukan didapatkan variabel rasio PAD terhadap total pendapatan daerah memiliki hubungan secara positif signifikan terhadap pertumbuhan ekonomi kabupaten/kota di Provinsi Sumatera Utara tahun 2011-2019. Variabel rasio PAD memiliki koefisien regresi sebesar 0.009787 berarti kenaikan satu persen variabel rasio PAD, dapat menaikkan pertumbuhan ekonomi sebesar 0,009787 persen dengan asumsi ceteris paribus. Dengan demikian diharapkan pemerintah kabupaten/kota di Provinsi Sumatera Utara dapat memfokuskan peningkatan rasio PAD untuk menghasilkan peningkatan pertumbuhan ekonomi. Hasil ini didukung oleh Kusumawati dan Wiksuana (2018), tingginya rasio PAD akan diikuti pertumbuhan ekonomi. Begitu juga Nasution (2010) yang dalam penelitiannya mengatakan bahwa dengan peningkatan PAD dapat membantu pemerintah untuk mencapai kemandirian daerah dan ekonomi yang lebih baik.

Berdasarkan hasil yang diperoleh dari analisis yang dilakukan didapatkan variabel rasio DBH terhadap total pendapatan daerah memiliki hubungan secara negatif tetapi tidak signifikan terhadap pertumbuhan ekonomi kabupaten/kota di Provinsi Sumatera Utara tahun 2011-2019. Variabel rasio DBH memiliki koefisien regresi sebesar $-0,044689$ berarti kenaikan satu persen variabel rasio $\mathrm{DBH}$, dapat menurunkan pertumbuhan ekonomi sebesar 0,044689 persen dengan asumsi ceteris paribus.

Berdasarkan hasil yang diperoleh dari analisis yang dilakukan didapatkan variabel rasio DAU terhadap total pendapatan daerah memiliki hubungan secara negatif tetapi tidak signifikan terhadap pertumbuhan ekonomi kabupaten/kota di Provinsi Sumatera Utara tahun 2011-2019. Variabel rasio DAU memiliki koefisien regresi sebesar $-0,002602$ berarti kenaikan satu persen variabel rasio DAU, dapat menurunkan pertumbuhan ekonomi sebesar 0,002602 persen dengan asumsi ceteris paribus.

Berdasarkan hasil yang diperoleh dari analisis yang dilakukan didapatkan variabel rasio DAK terhadap total pendapatan daerah memiliki hubungan secara positif signifikan terhadap pertumbuhan ekonomi kabupaten/kota di Provinsi Sumatera Utara tahun 2011-2019. Variabel rasio DAK memiliki koefisien regresi sebesar 0,008467 berarti kenaikan satu persen variabel rasio DAK, dapat menaikkan pertumbuhan ekonomi sebesar 0,008467 persen dengan asumsi ceteris paribus. Pemerintah kabupaten/kota di Provinsi Sumatera Utara dapat menambah rasio DAK untuk kepentingan pembangunan sarana dan prasarana dasar ynag berguna untuk peningkatan ekonomi masyarakat. Hasil ini didukung oleh Qomariyahti dan Hermanto (2017) bahwa pemanfaatan DAK dengan memfokuskan pada kegiatan investasi dalam hal ini seperti pembangunan, perbaikan serta peningkatan termasuk belanja fisik sarana dan prasarana dasar akan menjadi modal yang baik masyarakat untuk melaksanakan aktivitas perekonomian. Begitu juga penelitian Oktafia, Soelistyo dan Arifin (2018) bahwa DAK berpengaruh secara positif signifikan terhadap PDRB di daerah Provinsi Jawa Timur.

\section{Efek Individu}

Terpilihnya model fixed effect menjadikan model terpilih memiliki efek individu bagi masing-masing daerah yang berpengaruh terhadap PDRB. Kabupaten/kota dengan efek individu terbesar didapatkan oleh Kota Medan yakni sebesar 2,69826713 persen. Nilai ini memberikan gambaran bahwa apabila seluruh variabel bebas bernilai konstan maka kota Medan akan memiliki nilai pertumbuhan ekonomi tertinggi di Provinsi Sumatera Utara. Sementara itu, kabupaten/kota yang memiliki efek individu terkecil adalah Kabupaten Pakpak Bharat yakni -2.236862287 persen. Nilai ini memberikan gambaran bahwa apabila seluruh variabel bebas bernilai konstan maka Kabupaten Pakpak Bharat akan memiliki nilai pertumbuhan ekonomi terendah di Provinsi Sumatera Utara.

\section{KESIMPULAN}

Sesuai dengan hasil dan pembahasan setelah dianalisis, kesimpulan yang diperoleh adalah secara umum pertumbuhan ekonomi kabupaten/kota di Provinsi Sumatera Utara periode tahun 2011 - 2019 cenderung mengalami fluktuasi dengan peningkatan tidak begitu tinggi. Sementara itu, secara umum rasio PAD dan rasio DAK mengalami peningkatan. Untuk rasio DBH dan rasio DAU mengalami penurunan. Hasil analisis penelitian diperoleh secara parsial rasio PAD dan rasio DAK berpengaruh secara positif signifikan terhadap pertumbuhan ekonomi sedangkan rasio DBH dan rasio DAU berpengaruh negatif tidak signifikan terhadap pertumbuhan ekonomi.

\section{DAFTAR PUSTAKA}

Eliza, Z., Muhammad, S., \& Nasir, M. (2014). Analisis Pengaruh Dana Perimbangan Terhadap Pertumbuhan PDRB Di Provinsi Aceh. Jurnal Ilmu Ekonomi, 2(1), 44-54. ISSN 2302-0172. 
Greene, W.H. (2003). Econometric Analysis (5th ed). New Jersey: Prentice Hall.

Kusumawati, L., \& Wiksuana, I. (2018). Pengaruh Pendapatan Daerah Terhadap Pertumbuhan Ekonomi di Wilayah SARBAGITA Provinsi Bali. E-Jurnal Manajemen, 7(5), 2592-2620. https://doi.org/10.24843/EJMUNUD.2018.v07.i05.p12

Litvack, Jennie, et al. (1998). Decentralization in Developing Country. The World Bank, Washington DC, USA.

Martinez, V.J., \& McNab, R. (2003). Fiscal decentralization and economic growth. World Development, 31(9), 1697-1616.

Nasution, H.S. (2010). Analisis Faktor-Faktor Yang Mempengaruhi Pertumbuhan Produk Domestik Regional Bruto Era Desentralisasi Fiskal di Provinsi Banten Periode 2001:1-2009:4. Media Ekonomi, 18(2), 2948. 20 Mei 2021. https://dx.doi.org/10.25105/me.v18i2.2250

Oates, Wallace E. (1999). An Essay on Fiscal Federalism. Journal of Economic Literature, 37(3), 1120-149.

Oktafia, A.M., Soelistyo, A., \& Arifin, Z. (2018). Pengaruh Pendapatan Asli Daerah (PAD), Dana Alokasi Umum (DAU), Dana Alokasi Khusus (DAK) Terhadap Produk Domestik Regional Bruto (PDRB) Kabupaten/Kota di Provinsi Jawa Timur. Jurnal Ilmu Ekonomi, 2(1), 53-62.

Qomariyahti, N.D., \& Hermanto, S.B. (2017). Pengaruh PAD, DAU, DAK dan Belanja Modal Terhadap Pertumbuhan Ekonomi. Jurnal Ilmu dan Riset Akuntansi, 6(11). e-ISSN: 2460-0585.

Rahman, F. (2012). Desentalisasi Fiskal dan Minimnya Pemabngunan di Indonesia. Jurnal Administrasi dan Kebijakan Publik UNISMA, 1(2).

Todaro, M.P. (2006). Economic Development (7th ed). New York: Addition Wesley Longman, Inc.

World Bank. (1997). On Line Source Book on Decentralization and Rular Development. Decentralization Thematic Team, SDA. 